\title{
ANALISIS DEBIT LIMPASAN DAN PENANGGULANGANNYA (STUDI KASUS - POKA PERUMNAS, KEL. TIHU, KEC. TELUK AMBON)
}

\author{
Rafel Alberthus ${ }^{1}$, M. R. Ayal'2, C. G. Buyang ${ }^{3}$ \\ ${ }^{1}$ Mahasiswa Program Sarjana Program Studi Teknik Sipil Fakultas Teknik Universitas Pattimura Ambon \\ Email : rafelalberthus@gmail.com \\ ${ }^{2}$ Dosen Program Studi Teknik Sipil Fakultas Teknik, Universitas Pattimura Ambon \\ Email : ronal.ayal@fatek.unpatti.ac.id \\ ${ }^{3}$ Dosen Program Studi Teknik Sipil Fakultas Teknik Universitas Pattimura Ambon \\ Email : cg.buyang@fatek.unpatti.ac.id
}

\begin{abstract}
Abstrak
Daerah Poka Perumnas pada saat musim penghujan dengan intensitas yang tinggi sering terjadi genangan air dan banjir pada daerah kajian, karena saluran drainase yang ada tidak mempunyai sistem pembuangan yang baik dan dipenuhi oleh sedimentasi. Tujuan penelitian ini untuk menghitung besar debit limpasan, besar debit air buangan dan solusi penanggulangan pada saluran drainase eksisting. Analisis hidrologi curah hujan rancangan 10 tahun dengan distribusi Log Person Type III, debit banjir periode ulang 10 tahun dengan metode rasional. Analisis jumlah penduduk dengan metode geometrik. Analisis debit kumulatif dildapatkan dengan debit domestik dan debit banjir rencana kalaulang 10 tahun. Untuk analisis hidrolika dilakukan untuk mengetahui kapasitas saluran eksisting dan solusi penanggulangan. Berdasakan hasil analisis besar debit limpasan periode ulang 10 tahun $\left(\mathrm{Q}_{10 \mathrm{thn}}\right)$ maksimal sebesar $0,108753 \mathrm{~m}^{3} / \mathrm{det}$, debit minimum sebesar $0,030072 \mathrm{~m}^{3} / \mathrm{det}$, debit air kotor pada sistem drainase akibat pertambahan jumlah penduduk sebesar $0,0000283 \mathrm{~m}^{3} /$ det (debit maksimal) pada saluran $\mathrm{K} 1$ dan debit minimum terjadi pada saluran K15 sebesar $0,0000048 \mathrm{~m}^{3} / \mathrm{det}$. Solusi penanggulangan yang terjadi pada sistem drainase terhadap beban debit yang harus di tampung terdapat beberapa saluran yang tidak mampu menampung beban debit sehingga perlu dievaluasi dengan memperbesar dimensi saluran dan normalisasi saluran yang ada seperti saluran nomor K1 dengan dimensi lebar $(B)$ 0,86 $\mathrm{m}$ dan tinggi $(H)$ 0,95 m, saluran nomor K12 dengan dimensi lebar $(B) 0,50 \mathrm{~m}$ dan tinggi $(H) 0,60 \mathrm{~m}$.
\end{abstract}

Kata Kunci : Debit limpasan, Kapasitas saluran, Penanggulangan

\begin{abstract}
Poka Perumnas District, when come to the rainy season with high intensity ussualy occur water and flood in the area of study, because the drainage channel is not have a good disposal system and was fulfilled by sedimentation. The purpose of this research are to calculate number of discharge runoff, number of large discharge wastewater and solutions on existing drainage channels. Hydrological analysis of the draft rainfall of 10 years with the distribution of Log Person Type III, discharge flood period of 10 years by rational method. Population forecasting used geometric methods. Cumulative debits analysis was completed by the domestic debit and flood discharge plan for 10 years. For Hydraulics analysis used to know the capacity of existing channels and countermeasures solutions. Based on the results of a large analysis runoff period forlo years, maximum water discharge is $0.108753 \mathrm{~m} 3 / \mathrm{sec}$, minimum water discharge is $0.030072 \mathrm{~m} 3 / \mathrm{sec}$, the discharge of dirty water in the drainage system due to the increased population is $0.0000283 \mathrm{m3} / \mathrm{sec}$ (maximum discharge) on the channel $\mathrm{Kl}$ and the minimum discharge occurs in the $K 15$ channel of $0.0000048 \mathrm{m3} / \mathrm{sec}$. Countermeasures solution that occurs in the drainage system against the discharge load should be in capacity there are several channels that can not accommodate the discharge load so it needs to be evaluated by enlarging the channel dimension and normalization of existing channels such as channel number K1 with
\end{abstract}


dimension width (b) $0.86 \mathrm{~m}$ and height (h) $0.95 \mathrm{~m}, \mathrm{~K} 12$ with dimension width (b) $0.50 \mathrm{~m}$ and height (h) $0.60 \mathrm{~m}$

Keywords: Water discharge, channel capacity, countermeasures solution.

\section{PENDAHULUAN}

Dengan semakin meningkatnya intensitas air hujan pada musim hujan, bencana banjir hampir selalu terjadi di beberapa daerah di Indonesia, salah satunya adalah di daerah Poka Perumnas, Kelurahan Tihu, Kecamatan Teluk Ambon, Kota Ambon pada saat musim penghujan dengan intensitas yang tinggi sering terjadi genagan air dan banjir pada daerah kajian, karena saluran drainase yang ada tidak mempunyai sistem pembuangan yang baik dan dipenuhi oleh sedimentasi. Berdasarkan permasalahan di atas, maka yang menjadi rumusan masalah yaitu berapa besar debit limpasan, besar debit air buangan dan solusi penanggulangan pada saluran drainase eksisting. Penelitian ini bertujuan untuk menghitung dan mengetahui besar debit limpasan, besar debit air buangan dan solusi penanggulangan pada saluran drainase eksisting.

\section{STUDI PUSTAKA}

Curah hujan yang diperlukan untuk penyusunan suatu rancangan pengendalian banjir adalah curah hujan rata-rata di seluruh daerah yang bersangkutan, bukan curah hujan pada satu titik tertentu. Curah hujan ini disebut curah hujan ratarata daerah dan dinyaakan dalam satuan $\mathrm{mm}$ (Sosrodarsosno.1993:27).curah huajn daerah dapat diperkirakan dari beberapa titik pengamatan curah hujan pada daerah yang ditinjau. Cara-cara yang biasa digunakan antara lain metode rata-rata aljabar, metode polygon Thiessen, dan metode Iohyet.

\subsection{Analisa Hidrologi}

Dalam perrencanaan curah hujan rancangan dapat digunakana analaisa dengan cara statistik, dimana terdapat beberapa jenis distribusi frekuensi dalam statistik yang umum digunakan dalam bidang hidrologi, salah sataunya adalalah distribusi Log Pearson Type III.

Prosedur untuk menghitung curah hujan rancangan dengan distribusi Log Pearson Type III adalah sebagai berikut:

- Data curah huajn maksimu (Xi) diubah menjadi bentuk Logaritma (Log X)

- Dihitung nilai Logaritma Rata-rata (Log X)

- Hitung nilai rata-ratanya :

$$
\overline{\log X}=\frac{\sum \log X}{n}
$$

(CD.Soemarto, 1999)

- Hitung nilai deviasi standarnya dari $\log X$ :

$$
\begin{aligned}
& \overline{S \log X}=\sqrt{\frac{\sum(\log X-\overline{\log X})^{2}}{n-1}} \ldots \ldots \ldots \ldots \ldots . \quad \text { (pers.2) } \\
& \text { (CD. Soemarto, 1999) }
\end{aligned}
$$

- Hitung nilai koefisien kemencengan

$$
\begin{aligned}
& C s=\frac{n \sum_{i=1}^{n}(\log X-\overline{\log X})^{3}}{(n-1)(n-2)(\bar{S} \log X)^{3}} \ldots \ldots \ldots \ldots \ldots . . \quad \quad \text { (pers.3) } \\
& \text { (CD.Soemarto, 1999) }
\end{aligned}
$$

Sehingga persamaan garis lurusnya dapat ditulis :

$$
\log R t=\overline{\log X}-G t(\overline{S \log X}) \quad \ldots \ldots \ldots . \quad \quad \text { (pers.4) }
$$

Harga faktor Gt untuk sebaran Log Pearson II dapat dihitung dengan interpolasi

- Menentukan anti log dari log Rt, untuk mendapat nilai Rt yang diharapkan terjadi pada tingkat peluang atau periode tertentu sesuai dengan nilai Csnya.

- Hitung logaritma hujan atau banjir dengan periode ulang $\mathrm{T}$ dengan rumus :

$\log X_{i}=\log X_{r t}+k . s$

(pers.5)

Dimana : $\mathrm{S}=$ Standar deviasi.

$X_{i}=$ Titik tengah tiap interval kelas (mm).

$\mathrm{X}_{\mathrm{rt}}=$ Rata-rata hitungan $(\mathrm{mm})$.

$\mathrm{K}=$ Variabel standar (standarized variable), tergantung Cs.

\subsection{Debit Banjir Rancangan}

Untuk menentukan debit banjir rancangan atau kapasitas saluran drainase harus dihitung terlebih dahulu jumlah air hujan dan jumlah air rumah tangga yang akan melewati saluran dalam daerah perencanaan. Debit rancangan $\left(\mathrm{Q}_{\text {renc }}\right)$ adalah jumlah dari debit air hujan $\left(\mathrm{Q}_{\mathrm{ah}}\right)$ dan debit air rumah tangga ( $\left.\mathrm{Q}_{\mathrm{ak}}\right)$

$\left(\mathrm{Q}_{\mathrm{renc}}\right)=\left(\mathrm{Q}_{\mathrm{ah}}\right)+\left(\mathrm{Q}_{\mathrm{ak}}\right) \quad \ldots \ldots \ldots \ldots \ldots \ldots \quad$ (pers.6) 
Dengan:

$\left(\mathrm{Q}_{\text {renc }}\right)=$ Debit rancangan $\left(\mathrm{m}^{3} / \mathrm{det}\right)$

$\left(\mathrm{Q}_{\mathrm{ah}}\right)=$ Debit air hujan $\left(\mathrm{m}^{3} / \mathrm{det}\right)$

$\left.\mathrm{Q}_{\mathrm{ak}}\right)=$ Debit air kotor $\left(\mathrm{m}^{3} / \mathrm{det}\right)$

\subsection{Debit Air Hujan}

Debit air hujan adalah besarnya debit maksimum yang mengalir di saluran drainase akibat hujan yang turun. Debit air hujan ini dapat dihitung dengan rumus rasional, dengan rumus ini dipengaruhi oleh koefisien pengaliran pada daerah perncanaan, intensitas hujan dan luas daerah perencanaan.

$\mathrm{Q}_{\mathrm{ah}}=0,278$. C. I. A

(pers.7)

Dengan:

$\mathrm{Q}_{\mathrm{ah}}=$ Debit aliran air limpasan ( $\mathrm{m}^{3} /$ detik)

$\mathrm{C}=$ Koefisien run off (berdasarkan standar baku)

I = Intensitas hujan $(\mathrm{mm} / \mathrm{jam})$

A $=$ Luas daerah pengaliran (ha)

$0,278=$ Konstanta

\subsection{Koefisien Pengaliran}

Koefisien pengaliran merupakan perbandingan jumlah air yang mengalir akibat turunnya hujan disuatu daerah dengan jumlah air hujan yang turun pada daerah tersebut. Besarnya koefisien pengaliran berubah dari waktu ke waktu dengan pemanfaatan lahan dan aliran sungai.

Pengaruh tata guna lahan pada aliran permukaan dinyatakan dalam koefisien aliran permukaan $(\mathrm{C})$, yaitu bilangan yang menunjukkan perbandingan antara besarnya aliran permukaan dan besarnya curah hujan. Apabila koefisien aliran permukaan ini merupakan salah satu indikator untuk menentukan kondisi fisik suatu daerah aliran permukaan suatu daerah aliran kawasan pemukiman.

\subsection{Intensitas}

Intensitas hujan adalah tinggi atau kedalaman air hujan per satuan waktu. Sifat umum hujan adalah semakin singkat hujan berlangsung, intensitasnya cenderung makin tinggi dan makin besar periode ulangnya makin tinggi pula intensitasnya.

Hubungan antara intensitas, lama hujan, dan frekuensi hujan dinyatakan dalam lengkung Intensitas-Durasi-Frekuensi (IDF $=$ IntensityDuration-Frequency Curve). Diperlukan data hujan jangka pendek, misalnya 5 menit, 10 menit, 30 menit, 60 menit dan jam - jam-an untuk membentuk lengkung IDF. Data hujan jenis ini hanya dapat diperoleh dari pos penakar hujan otomatis (Soemarto, 1995).
Untuk menghitung intensitas curah hujan, dapat digunakan metode mononobe:

$$
\begin{aligned}
& I=\frac{R_{24}}{24}\left(\frac{24}{t}\right)^{\frac{2}{3}} \quad \ldots \ldots \ldots \ldots \ldots . \quad \text { (pers.8) } \\
& \mathrm{tc}=\text { to }+\mathrm{td} \ldots \ldots \ldots \ldots \ldots \ldots \ldots \ldots \ldots \text { (pers.9) } \\
& t_{o}=\left(\frac{2}{3} \times 3,28 \times L \times \frac{n}{\sqrt{s}}\right) \text { menit } \ldots \ldots \text { (pers.10) } \\
& t_{d}=\frac{L_{s}}{60 \mathrm{~V}} \text { menit } \quad \ldots \ldots \ldots \ldots \ldots . . . \quad \quad \text { (pers.11) }
\end{aligned}
$$

Dengan :

$$
\text { I = Intensitas curah hujan ( } \mathrm{mm} / \mathrm{jam})
$$

$\mathrm{t}=$ Lamanya curah hujan / durasi curah hujan (jam)

$\mathrm{R}_{24}=$ Curah hujan rencana dalam suatu periode ulang, yang nilainya didapat dari tahapan sebelumnya (tahapan analisis frekuensi).

$\mathrm{t}_{\mathrm{c}}=$ Waktu konsentrasi (jam)

$\mathrm{t}_{0} \quad=$ Inlet time (jam)

$\mathrm{t}_{\mathrm{d}}=$ Condouit time (jam)

$\mathrm{n} \quad=$ Angka kekasaran Manning

$\mathrm{S}=$ Kemiringan saluran

L = Panjang lintasan aliran di atas permukaan lahan $(\mathrm{m})$

$\mathrm{V}=$ Kecepatan aliran di dalam saluran (m/detik)

\subsection{Debit Air Kotor}

Debit air kotor adalah debit yang berasal dari air kotor bungan rumah tangga, bangunan gedunng, instalasi, dan sebagainya. Untuk memperkrakan jumlah air kotor yang akan dialirkan ke saluran drainase harus diketahui terlebih dahulu jumlah kebutuhan air rata-rata dan jumalah penduduk daerah perencanaan. Kebutuhan air bersih untuk daerah perencanaan adalah sebesar 150 liter/hari/orang dan diperkirakan besarnya air buangan yang masuk ke saluran pengumpul air buangan sebesar $90 \%$ dari kebutuhan standar air minum (Suhardjono, 1984 dalam Suroso dkk, 2014). Sehinga besarnya air kotor adalah:

$$
\begin{aligned}
\mathrm{q} & =90 \% \text { x } 150 \text { liter/orang/hari } \\
& =135 \text { liter/orang/hari } \\
\mathrm{Q}_{\mathrm{ak}} & =\mathrm{Q}_{\mathrm{ab}} \mathrm{X} \mathrm{A}
\end{aligned}
$$

Dengan:

$\mathrm{Q}_{\mathrm{ak}}=$ Debit air kotor $\left(\mathrm{m}^{3} / \mathrm{det}\right)$

$\mathrm{Q}_{\mathrm{ab}}=$ Debit air buangan $\left(\mathrm{m}^{3} / \mathrm{det}\right)$

$\mathrm{A}=$ Luas saluran drainase (ha)

\subsection{Prediksi Jumlah Penduduk}

Dalam perencanaan suatu sisitem jaringan drainase perlu diketahui besarnya jumlah penduduk untuk memperkirakan jumlah air buangan atau limbah yang akan masuk kedalam saluran drainase. Jumlah pendudk dapat dihitung sesuai dengan 
kepadatan penduduk di daerah kajian dan dapat dihitung dengan metode geometrik.

Metode Geometrik:

$$
\begin{aligned}
& \mathrm{P}_{\mathrm{n}}=\mathrm{P}_{\mathrm{o}}(1+\mathrm{r})^{\mathrm{n}} \ldots \ldots \ldots \ldots . . . \\
& r=\frac{P_{\mathrm{O}}-P_{t}}{t}
\end{aligned}
$$

Dengan:

$\mathrm{P}_{\mathrm{n}}=$ Jumlah penduduk tahun ke-n (jiwa)

$\mathrm{P}_{\mathrm{o}}=$ Jumlah penduduk pada awal tahun

proyeksi(jiwa)

$\mathrm{P}_{\mathrm{t}}=$ Jumlah penduduk akhir tahun proyeksi (jijwa)

$\mathrm{t}=$ Banyaknya tahun sebelum analisa

$\mathrm{r}=$ Angka pertumbuhan penduduk / tahun $(\%)$

$\mathrm{n}=$ Preode waktu yang ditinjau

\subsection{Evaluasi dan Perencanaan Ulang Saluran Drainase}

Evaluasi sistem jaringan saluran drainase yang ad digunakan untuk mengetahui saluran-saluran yang tidak mampu menampung debit air hujan dengan intensitas tertentu dan limbah domestik sebagai penyebab terjadinya genangan. Jika $\mathrm{Q}_{\mathrm{ranc}}>$ $\mathrm{Q}_{\mathrm{kap}}$ maka saluran perlu di rencanakan ulang, sedangkan jika $\mathrm{Q}_{\text {ranc }}<\mathrm{Q}_{\mathrm{kap}}$ maka tidak perlu perencanaan ulang.

\subsection{Kapasitas Saluran Drainase}

Besarnya kapasitas saluran drainase ditentukan berdasarkan dimensi saluran pada peta jaringan drainase. Rumus untuk perhitungan kapasitas saluran adalah sebagai berikut:

$V=\frac{1}{n} \times R^{2 / 3} \times S^{1 / 2} \quad \ldots \ldots \ldots \ldots$

(pers.15)

$Q_{\text {kap }}=A \times V \quad \ldots \ldots \ldots \ldots$.

(pers.16)

Dengan :

$$
\begin{aligned}
Q_{\text {kap }} & =\text { Debit saluran }\left(\mathrm{m}^{3} / \text { det }\right) \\
\mathrm{V} & =\operatorname{Kecepatan} \text { aliran }(\mathrm{m} / \mathrm{det}) \\
\mathrm{A} & =\text { Luas penampang basah saluran }\left(\mathrm{m}^{3}\right) \\
\mathrm{n} & =\text { Angka kekasaran saluran }(\mathrm{m}) \\
\mathrm{R} & =\text { Jari-jari hidrolis saluran }(\mathrm{m}) \\
\mathrm{S} & =\text { Kemiringan dasar saluran }
\end{aligned}
$$

\section{METODE PENELITIAN}

Berdasarkan data-data yang diperoleh mengenai peta topografi, peta jaringan drainase, data curah hujan (selama 10 tahun) dari tahun 2009 - 2018, data jumlah penduduk, maka langkah-langkah pengolahan datanya adalah sebagai berikut :

1. Perhitungan curah hujan rata-rata dengan mencari curah hujan harian maksimum setiap tahunnya.
2. Perhitung curah hujan rancangan menggunakan metode Log Pearson III dengan pertimbangan metode ini dapat digunakan untuk berbagai sebaran data. Untuk pengujian kesesuaian distribusi mengunakan Uji Chi-Square

3. Perhitungan luas daerah pengaliran menggunakan peta topografi dan peta jaringan drainase yang ada, sehingga dapat diketahui luas daerah yang mempengaruhi pengaliran pada suatu saluran.

4. Perhitungan intensitas hujan menggunakan curah hujan rancangan yang sudah didapatkan dengan metode Log Pearson III. Besarnya intensitas hujan ini dipengaruhi oleh lamanyacurah hujan.

5. Perhitungan debit air hujan dengan menggunakan rumus Rasional, dimana data yang dibutuhkan untuk rumus Rasional adalah luas daerah pengaliran (A), koefisien pengaliran (C), dan intensitas hujan (I).

6. Perhitungan debit air kotor dihitung dengan mengalikan kebutuhan air bersih dengan jumlah orang/penduduk yang berada pada luas daerah alirannya masing-masing, dimana jumlah orang/penduduk dihitung berdasarkan metode geometrik dan metode eksponensial

7. Perhitungan debit banjir rancangan dengan menjumlahkan debit air hujan dengan debit air kotor.

8. Perhitungan kapasitas saluran drainase didapatkan dari dimensi saluran drainase yang sudah ada.

9. Evaluasi saluran drainase dengan membandingkan debit banjir rancangan dengan kapasitas saluran drainase maka dapat diambil kesimpulan apakah suatu saluran perlu diperbaiki atau tidak. Jika debit banjir rancangan melebihi kapasitas saluran yang ada maka saluran perlu diperbaiki, akan tetapi jika debit banjir rancangan tidak melebihi kapasitas saluran yang ada maka saluran tersebut tidak perlu diperbaiki/direncanakan ulang.

\section{HASIL DAN PEMBAHASAN}

\subsection{Analisis Hidrologi}

Analisa curah hujan maksimum bertujuan untuk memproses data curah hujan yang diperoleh dari rekaman data curah hujan otomatis dan dianalisis data yang ada untuk perhitungan volume drainase. Penetuan curah hujan menggunakan metode rata-rata aljabar. 
Tabel 1. Curah Hujan Maksimum Harian

\begin{tabular}{|c|c|c|}
\hline No & Tahun & $\begin{array}{c}\text { Curah Hujan } \\
\text { Max Harian }\end{array}$ \\
\hline 1 & 2009 & 262,80 \\
\hline 2 & 2010 & 170,00 \\
\hline 3 & 2011 & 97,30 \\
\hline 4 & 2012 & 223,90 \\
\hline 5 & 2013 & 360,40 \\
\hline 6 & 2014 & 348,10 \\
\hline 7 & 2015 & 313,07 \\
\hline 8 & 2016 & 62,86 \\
\hline 9 & 2017 & 184,80 \\
\hline 10 & 2018 & 32,12 \\
\hline
\end{tabular}

Sumber: Hasil Analisa curah hujan

\subsection{Analisis Frekuensi Curah Hujan}

Data curah huajn yang digunakan berupa data curah hujan harian maksimum selama 10 tahun (2009-2018) pada stasiun Pattimura Ambon, Kec. Teluk Ambon. Metode analisa hujan rancangan yang digunakan adalah metode Log Person Type III.

Tabel 2. Perhitungan metode distribusi Log Person type III

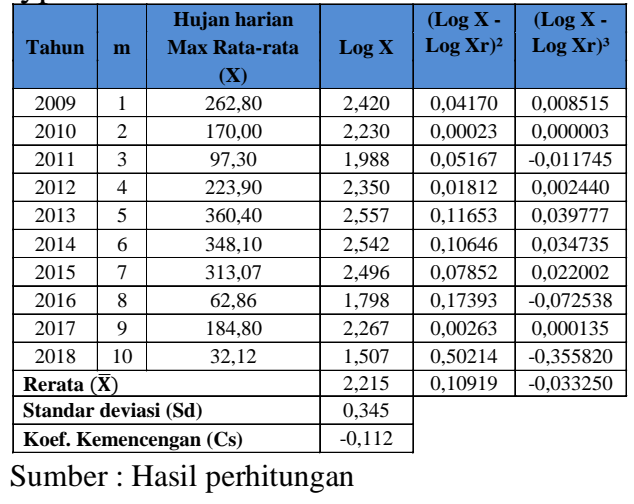

Dari data hujan harian maksimum tahunan seperti diberikan dalam Tabel 1. Dihitung nilai $X=\log X$, seperti diberikan dalam Tabel 4.2. Dari data $X=$ Log $X$, dihitung nilai rerata $(\bar{X})$, standar deviasi (Sd) dan koefisien asimetri ( $\mathrm{Cs}$ ) yang dihitung sebagai berikut. Perhitungan curah hujan rencana metode distribusiDimana nilai $(\mathrm{K})$ dapat dilihat dari (Bambang Triatmodjo), yang dipengaruhi oleh nilai Cs. Karena nilai $\mathrm{Cs}=-0,112 \approx-0,1$ maka, dapat ditarik kesimpulan bahwa nilai koef. $\mathrm{G}=(0,017)$ untuk kala ulang 2 tahun.

Tabel 3. Perhitungan curah hujan rancangan metode distribusi Log Person type III

\begin{tabular}{|c|c|c|c|c|c|c|}
\hline No & $\begin{array}{c}\text { Kala ulang } \\
(\text { Tr })\end{array}$ & Rata-rata & Std Dev. & \multirow{2}{*}{$\mathbf{K}$} & \multicolumn{2}{|c|}{$\begin{array}{c}\text { Curah Hujan } \\
\text { Rancangan }(\mathbf{R})\end{array}$} \\
\cline { 5 - 7 } & $($ Tahun $)$ & $(\mathbf{L o g} \mathbf{x})$ & $(\mathbf{S})$ & & $\mathbf{L o g}$ & $\mathbf{m m}$ \\
\hline 1 & 2 & 2,215 & 0,345 & 0,017 & 2,221 & 166,455 \\
\hline 2 & 5 & 2,215 & 0,345 & 0,846 & 2,508 & 321,871 \\
\hline 3 & 10 & 2,215 & 0,345 & 1,270 & 2,654 & 450,979 \\
\hline 4 & 25 & 2,215 & 0,345 & 0,716 & 2,463 & 290,250 \\
\hline
\end{tabular}

Sumber : Hasil perhitungan

\subsection{Uji Chi Kuadrat}

Pengujian kecocokan sebaran menggunakan metode chi-kuadrat :

Tabel 4. Perhitungan uji Chi Kuadrat

\begin{tabular}{|c|c|c|c|c|c|c|c|c|c|}
\hline No & \multicolumn{5}{|c|}{ Kemungkinan } & Ef & Of & Ef - Of & $(\mathrm{Ef}-\mathrm{Of})^{2} / \mathrm{Ef}$ \\
\hline 1 & 8,915 & $\leq$ & $\mathrm{x}$ & $\leq$ & 90,985 & 2,5 & 1 & 1,5 & 0,900 \\
\hline 2 & 90,985 & $\leq$ & $\mathrm{x}$ & $\leq$ & 173,055 & 2,5 & 3 & $-0,5$ & 0,100 \\
\hline 3 & 173,055 & $\leq$ & $\mathrm{x}$ & $\leq$ & 255,125 & 2,5 & 4 & $-1,5$ & 0,900 \\
\hline 4 & 255,125 & $\leq$ & $\mathrm{x}$ & $\leq$ & 337,195 & 2,5 & 2 & 0,5 & 0,100 \\
\hline Jumlah & & & & & & & 10 & $\mathbf{X}^{2}$ & 2,000 \\
\hline & & & & & & & & $\mathrm{X}^{2} \mathrm{Cr}$ & 5,991 \\
\hline
\end{tabular}

Sumber : Hasil perhitungan

Dari hasil perhitungan di atas di dapat nilai $\mathrm{X}^{2}$ sebesar 2,000 yang kurang dari nilai $\mathrm{X}^{2}$ pada tabel Chi-Kuadrat yang besarnya adalah 5,991 (Bambang Triatmodjo,2008). Maka dari pengujian kecocokan penyebaran distribusi Log Person type III dapat diterima.

\subsection{Perhitungan Debit Limpasan $\left(Q_{a h}\right)$}

Tabel 5. Tata guna lahan

\begin{tabular}{|c|c|c|c|}
\hline No & Tata guna lahan & Koef C & $\begin{array}{c}\text { Luas } \\
\text { (Ha) }\end{array}$ \\
\hline 1 & Multiunit, terpisah & 0,40 & 23,02 \\
\hline
\end{tabular}

Sumber : Hasil perhitungan

Tabel 6. Perhitungan luas area saluran drainase

\begin{tabular}{|c|c|c|c|c|c|c|c|}
\hline No & $\begin{array}{c}\text { Nama } \\
\text { Saluran }\end{array}$ & $\begin{array}{c}\text { Sloop } \\
(\mathbf{S})\end{array}$ & $\begin{array}{c}\text { Panjang } \\
\text { Saluran } \\
(\mathbf{m})\end{array}$ & $\begin{array}{c}\text { Lebar } \\
(\mathbf{m})\end{array}$ & $\begin{array}{c}\text { Tinggi } \\
(\mathbf{m})\end{array}$ & $\begin{array}{c}\text { Luas } \\
\left(\mathbf{m}^{2}\right)\end{array}$ & $\begin{array}{c}\text { Luas } \\
\text { Area } \\
(\mathbf{H a})\end{array}$ \\
\hline 1 & $\mathrm{~K} 1$ & 0,0046 & 219,5 & 0,85 & 0,92 & 187 & 0,0187 \\
\hline 2 & $\mathrm{~K} 2$ & 0,0046 & 219,5 & 0,84 & 0,46 & 184 & 0,0184 \\
\hline 3 & $\mathrm{~K} 3$ & 0,0110 & 91,15 & 0,70 & 0,70 & 64 & 0,0064 \\
\hline 4 & $\mathrm{~K} 4$ & 0,0113 & 176,68 & 0,72 & 0,72 & 127 & 0,0127 \\
\hline 5 & $\mathrm{~K} 5$ & 0,0109 & 183,88 & 0,82 & 1,04 & 151 & 0,0151 \\
\hline 6 & $\mathrm{~K} 6$ & 0,0352 & 85,3 & 0,56 & 0,56 & 48 & 0,0048 \\
\hline 7 & $\mathrm{~K} 7$ & 0,0105 & 191,1 & 0,78 & 0,38 & 149 & 0,0149 \\
\hline 8 & $\mathrm{~K} 8$ & 0,0100 & 100 & 0,60 & 0,67 & 60 & 0,0060 \\
\hline 9 & $\mathrm{~K} 9$ & 0,0280 & 71,43 & 0,59 & 0,61 & 42 & 0,0042 \\
\hline 10 & $\mathrm{~K} 10$ & 0,0442 & 90,4 & 0,55 & 0,66 & 50 & 0,0050 \\
\hline 11 & $\mathrm{~K} 11$ & 0,0553 & 90,4 & 0,53 & 0,75 & 48 & 0,0048 \\
\hline 12 & $\mathrm{~K} 12$ & 0,0128 & 78 & 0,42 & 0,50 & 33 & 0,0033 \\
\hline 13 & $\mathrm{~K} 13$ & 0,0100 & 100 & 0,73 & 0,67 & 73 & 0,0073 \\
\hline 14 & $\mathrm{~K} 14$ & 0,0077 & 129,5 & 0,80 & 0,63 & 104 & 0,0104 \\
\hline 15 & $\mathrm{~K} 15$ & 0,0134 & 74,63 & 0,42 & 0,50 & 31 & 0,0031 \\
\hline 16 & $\mathrm{~K} 16$ & 0,0162 & 61,68 & 0,70 & 0,70 & 43 & 0,0043 \\
\hline
\end{tabular}

Sumber : Hasil perhitungan 
Tabel 7. Perhitungan debit air hujan

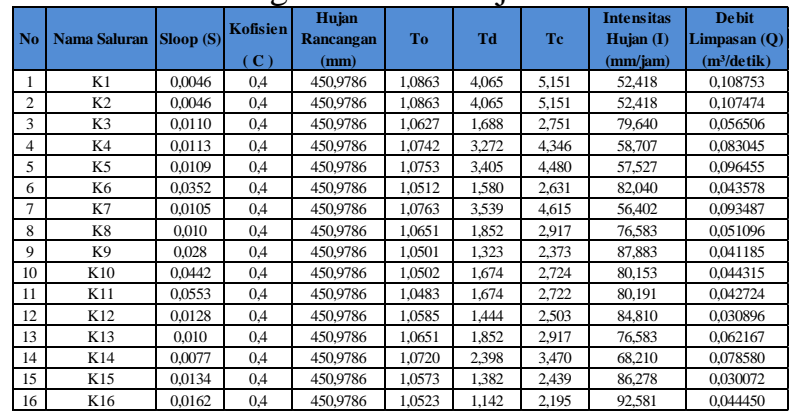

Sumber : Hasil perhitungan

\subsection{Perhitungan Debit Air Kotor $\left(Q_{a k}\right)$}

Perhitungan proyeksi pertumbuhan penduduk menggunakan rumus Metode Regresi Linier. Data jumlah penduduk lima tahun terakhir, yaitu tahun 2015, 2016, 2017, 2018 dan 2019 pada daerah Kel. Tihu, Kec. Teluk Ambon.

Tabel 8. Perhitungan jumlah penduduk

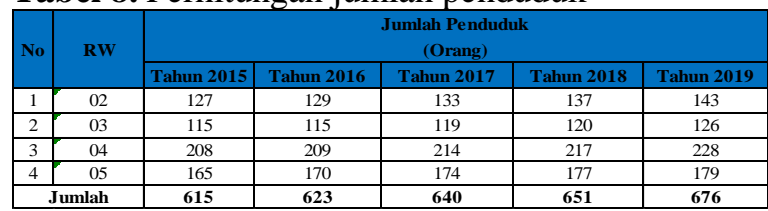

Sumber : Kelurahan Tihu, Kec. Teluk Ambon

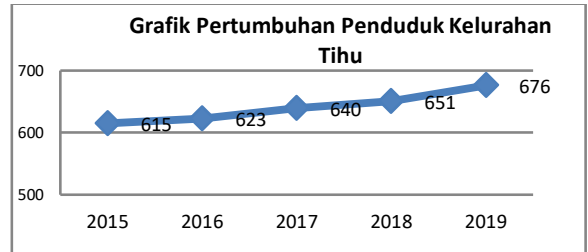

Gambar 1 : Grafik pertumbuhan penduduk Kel. Tihu

Tabel 9. Perhitungan analisa proyeksi jumlah penduduk

\begin{tabular}{|c|c|c|c|c|}
\hline \multirow[b]{2}{*}{ No } & \multirow[b]{2}{*}{ RW } & \multirow{2}{*}{$\begin{array}{l}\text { Laju pertumbuhan } \\
\text { penduduk }\end{array}$} & \multicolumn{2}{|c|}{ Penduduk (Orang) } \\
\hline & & & 2019 & 2029 \\
\hline 1 & 02 & $0,037 \%$ & 143 & 206 \\
\hline 2 & 03 & $0,037 \%$ & 126 & 181 \\
\hline 3 & 04 & $0,037 \%$ & 228 & 328 \\
\hline 4 & 05 & $0,037 \%$ & 179 & 257 \\
\hline & & umlah & 676 & 972 \\
\hline
\end{tabular}

Sumber : Hasil perhitungan

Tabel 10. Perhitungan debit air kotor pada saluaran drainase

\begin{tabular}{|c|c|c|c|c|c|}
\hline No & $\begin{array}{l}\text { Nama } \\
\text { Saluran }\end{array}$ & $\begin{array}{l}\text { Luas } \\
\left(\mathbf{m}^{2}\right)\end{array}$ & $\begin{array}{l}\text { Luas } \\
\text { (ha) }\end{array}$ & $\mathbf{Q}$ & $\begin{array}{c}\text { Debit air kotor } \\
\left(\mathrm{m}^{3} / \mathrm{det} / \mathrm{ha}\right)\end{array}$ \\
\hline 1 & K1 & 187 & 0,0187 & 0,00152 & 0,0000283 \\
\hline 2 & $\mathrm{~K} 2$ & 184 & 0,0184 & 0,00152 & 0,0000280 \\
\hline 3 & $\mathrm{~K} 3$ & 64 & 0,0064 & 0,00152 & 0,0000097 \\
\hline 4 & $\mathrm{~K} 4$ & 127 & 0,0127 & 0,00152 & 0,0000193 \\
\hline 5 & K5 & 151 & 0,0151 & 0,00152 & 0,0000229 \\
\hline 6 & K6 & 48 & 0,0048 & 0,00152 & 0,0000073 \\
\hline 7 & K7 & 149 & 0,0149 & 0,00152 & 0,0000226 \\
\hline 8 & K8 & 60 & 0,0060 & 0,00152 & 0,0000091 \\
\hline 9 & K9 & 42 & 0,0042 & 0,00152 & 0,0000064 \\
\hline 10 & K10 & 50 & 0,0050 & 0,00152 & 0,0000076 \\
\hline 11 & K11 & 48 & 0,0048 & 0,00152 & 0,0000073 \\
\hline 12 & K12 & 33 & 0,0033 & 0,00152 & 0,0000050 \\
\hline 13 & K13 & 73 & 0,0073 & 0,00152 & 0,0000111 \\
\hline 14 & K14 & 104 & 0,0104 & 0,00152 & 0,0000157 \\
\hline 15 & K15 & 31 & 0,0031 & 0,00152 & 0,0000048 \\
\hline 16 & K16 & 43 & 0,0043 & 0,00152 & 0,0000066 \\
\hline
\end{tabular}

Sumber : Hasil perhitungan

\subsection{Perhitungan Debit Rencana $\left(Q_{\text {ren }}\right)$}

Menghitung Debit Rencana $\left(\mathrm{Q}_{\text {ren }}\right)$ Untuk Kala

Ulang 10 Tahun.

Tabel 11. Perhitungan debit rencana

\begin{tabular}{|c|c|c|c|c|c|c|}
\hline No & $\begin{array}{c}\text { Nama } \\
\text { Saluran }\end{array}$ & $\begin{array}{c}\text { Luas } \\
\left(\mathbf{m}^{2}\right)\end{array}$ & $\begin{array}{c}\text { Luas } \\
(\mathbf{h a})\end{array}$ & $\begin{array}{c}\text { Debit Limpasan }(\mathbf{Q}) \\
\left(\mathbf{m}^{\mathbf{3}} / \mathbf{d e t} \mathbf{k}\right)\end{array}$ & $\begin{array}{c}\text { Debit air kotor } \\
\left(\mathbf{m}^{\mathbf{3}} / \mathbf{d e t} / \mathbf{h a}\right)\end{array}$ & $\begin{array}{c}\text { Debit Rencana } \\
(\mathbf{Q r})\end{array}$ \\
\hline 1 & $\mathrm{~K} 1$ & 187 & 0,0187 & 0,108753 & 0,0000283 & 0,108782 \\
\hline 2 & $\mathrm{~K} 2$ & 184 & 0,0184 & 0,107474 & 0,0000280 & 0,107502 \\
\hline 3 & $\mathrm{~K} 3$ & 64 & 0,0064 & 0,056506 & 0,0000097 & 0,056515 \\
\hline 4 & $\mathrm{~K} 4$ & 127 & 0,0127 & 0,083045 & 0,0000193 & 0,083065 \\
\hline 5 & $\mathrm{~K} 5$ & 151 & 0,0151 & 0,096455 & 0,0000229 & 0,096478 \\
\hline 6 & $\mathrm{~K} 6$ & 48 & 0,0048 & 0,043578 & 0,0000073 & 0,043585 \\
\hline 7 & $\mathrm{~K} 7$ & 149 & 0,0149 & 0,093487 & 0,0000226 & 0,093510 \\
\hline 8 & $\mathrm{~K} 8$ & 60 & 0,0060 & 0,051096 & 0,0000091 & 0,051105 \\
\hline 9 & $\mathrm{~K} 9$ & 42 & 0,0042 & 0,041185 & 0,00000064 & 0,041192 \\
\hline 10 & $\mathrm{~K} 10$ & 50 & 0,0050 & 0,044315 & 0,0000076 & 0,044323 \\
\hline 11 & $\mathrm{~K} 11$ & 48 & 0,0048 & 0,042724 & 0,0000073 & 0,042731 \\
\hline 12 & $\mathrm{~K} 12$ & 33 & 0,0033 & 0,030896 & 0,0000050 & 0,030901 \\
\hline 13 & $\mathrm{~K} 13$ & 73 & 0,0073 & 0,062167 & 0,0000111 & 0,062178 \\
\hline 14 & $\mathrm{~K} 14$ & 104 & 0,0104 & 0,078580 & 0,0000157 & 0,078596 \\
\hline 15 & $\mathrm{~K} 15$ & 31 & 0,0031 & 0,030072 & 0,0000048 & 0,030077 \\
\hline 16 & $\mathrm{~K} 16$ & 43 & 0,0043 & 0,044450 & 0,0000066 & 0,044456 \\
\hline
\end{tabular}

Sumber : Hasil perhitungan

\subsection{Kondisi Sistem Drainase Eksisting}

Sesuai dengan identifikasi lokasi studi, system drainase pada Poka Perumnas Kelurahan Tihu.

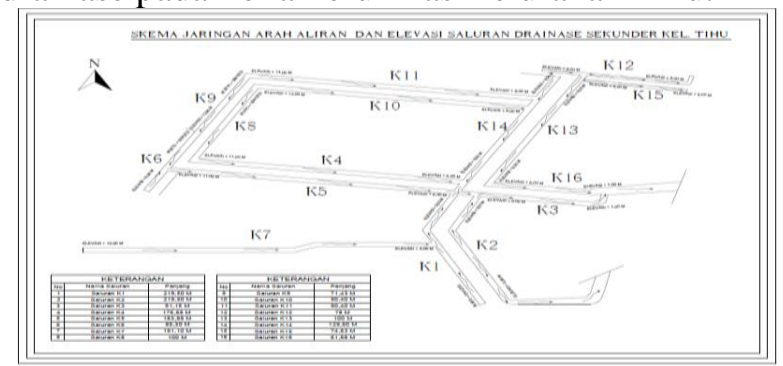

Gambar 2. Skema system drainase Kel. Tihu

Tabel 12. Perhitungan saluran drainase eksisting

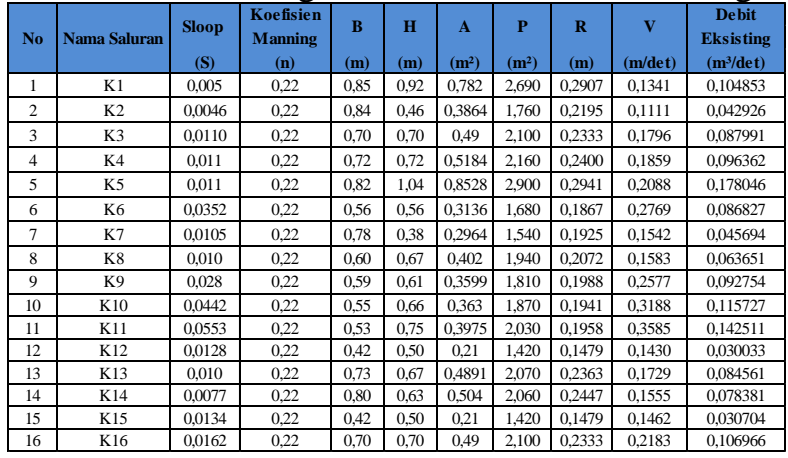

Sumber : Hasil perhitungan

Tabel 13. Perhitungan kapasitas saluran drainase

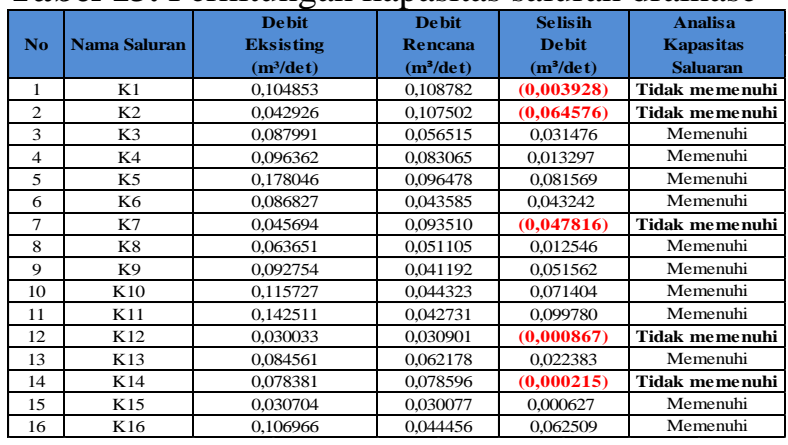

Sumber : Hasil perhitungan 


\subsection{Perhitungan Evaluasi Saluran Drainase}

Hasil analisis ada 5 titik saluaran yang menjadi tinjauan yang tidak mampu menampung debit rencana, dimana kapasitas saluran lebih kecil dari debit rencana.

Tabel 14. Perhitungan saluran drainase baru

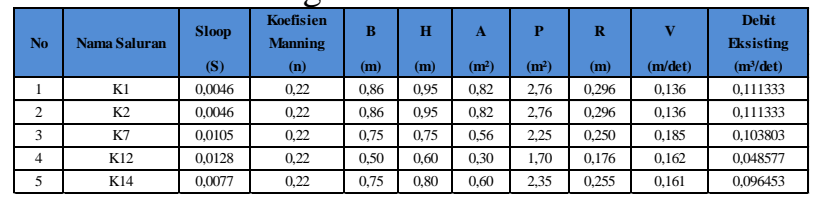

Sumber : Hasil perhitungan

\subsection{Kapasitas saluran drainase lama dan baru}

1. Arah Aliran dan Elevasi Saluran K1

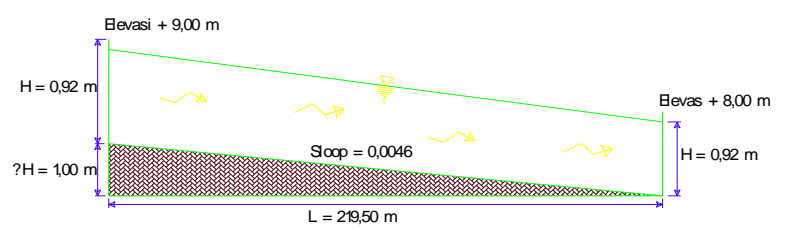

(a) Aliran Lama

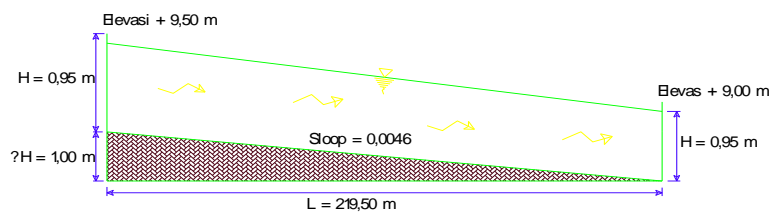

(b) Aliran Baru

Gambar 3. (a), (b) Arah aliran lama dan baru

2. Potongan Saluran Lama dan Baru K1

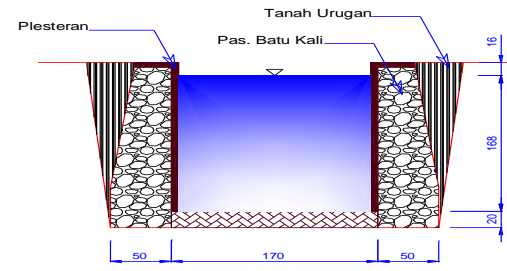

Potongan Saluran Drainase Lama K1 Skala 1:50

(a) Potongan saluran lama

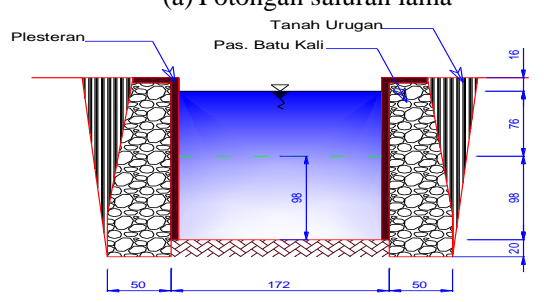

Potongan Saluran Drainase Baru K1 Skala 1:50

(b) Potongan saluran baru
Gambar 4. (a), (b) Potongan saluran lama dan baru

\subsection{Penanggulangan Sedimentasi Saluran Drainase}

Upaya penanggulangan sedimentasi tertuju pada 3 titik saluran drainase yang terdapat sedimentasi.

1. Saluran Drainase Lama dan Baru K2

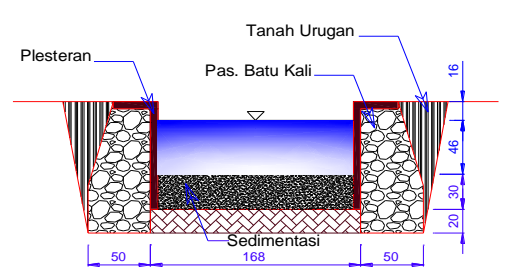

Potongan Saluran Drainase Lama K2

Skala 1:50

Keterangan :

Gambar 5. Potongan saluran lama

- $\quad$ Panjang $(\mathrm{L})=219,50 \mathrm{M}$

- $\quad$ Lebar $(B)=168 \mathrm{Cm}$

- Tinggi $(\mathrm{H})=76 \mathrm{Cm}$

- Tinggi Jagaan $(\mathrm{W})=16 \mathrm{Cm}$

- Debit Eksisting (QEksisting) $=0,042926 \mathrm{~m}^{3} / \mathrm{det}$

- Kecepatan Aliran (V) $=0,1111 \mathrm{~m} / \operatorname{det}$

- $\quad$ Sloop $(S)=0,0046$

- Tinggi Sedimentasi $=30 \mathrm{Cm}$

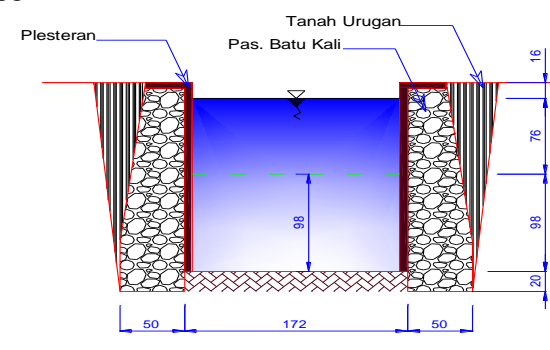

Potongan Saluran Drainase Baru K2 Skala 1:50

Gambar 6. Potongan saluran baru

Keterangan :

- Panjang $(L)=219,50 \mathrm{M}$

- $\quad \operatorname{Lebar}(B)=172 \mathrm{Cm}$

- $\quad$ Tinggi $(H)=174 \mathrm{Cm}$

- Tinggi Jagaan $(W)=16 \mathrm{Cm}$

- Debit Saluran Baru $\left(Q_{\text {Saluran baru }}\right)=0,111333 \mathrm{~m}^{3} / \mathrm{det}$

- Kecepatan Aliran $(V)=0,136 \mathrm{~m} / \mathrm{det}$

- $\quad \operatorname{Sloop}(S)=0,0046$

- Koefisien Menning $(n)=0,22$

- Saluran yang baru ditamabah tIngginya $=98 \mathrm{Cm}$

2. Saluran Drainase Lama dan Baru K14 


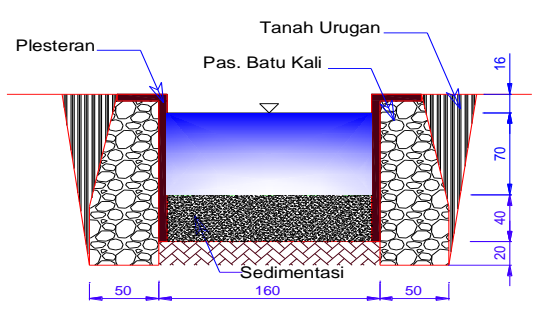

Potongan Saluran Drainase Lama K14

Skala 1:50

Gambar 7. Potongan saluran lama

Keterangan :

- Panjang $(\mathrm{L})=129,50 \mathrm{M}$

- $\operatorname{Lebar}(\mathrm{B})=160 \mathrm{Cm}$

- Tinggi $(\mathrm{H})=110 \mathrm{Cm}$

- Tinggi Jagaan $(\mathrm{W})=16 \mathrm{Cm}$

- Debit Eksisting $\left(Q_{\text {Eksisting }}\right)=0,078381 \mathrm{~m}^{3} /$ det

- Kecepatan Aliran $(\mathrm{V})=0,1555 \mathrm{~m} /$ det

- $\operatorname{Sloop}(S)=0,0077$

- Sedimentasi $=40 \mathrm{Cm}$

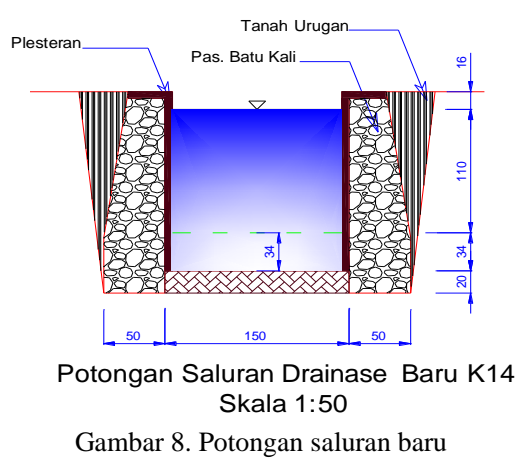

Keterangan :

Gambar 8. Potongan saluran baru

- Panjang $(L)=129,50 \mathrm{M}$

- Lebar $(B)=150 \mathrm{Cm}$

- Tinggi $(H)=150 \mathrm{Cm}$

- Tinggi Jagaan $(W)=16 \mathrm{Cm}$

- Debit Saluran Baru $\left(Q_{\text {Saluran baru }}\right)=0,096453 \mathrm{~m}^{3} / \mathrm{det}$

- Kecepatan Aliran $(V)=0,161 \mathrm{~m} / \mathrm{det}$

- $\operatorname{Sloop}(S)=0,0077$

- Koefisien Menning $(n)=0,22$

- Saluran yang baru ditamabah tingginya $=34 \mathrm{Cm}$

\section{PENUTUP}

\subsection{Kesimpulan}

Berdasarkan hasil analisis maka dapat diambil kesimpulan yaitu :

1. Debit rencana maksimal pada sistem drainase di daerah Kelurahan Tihu terjadi pada saluran K1 sebesar $0,108782 \mathrm{~m}^{3} /$ det dan besar debit rencana minimum adalah $0,030077 \mathrm{~m}^{3} /$ det pada saluran K15.

2. Besar debit limpasan yang terjadi pada sistem drainase di daerah Kelurahan Tihu adalah sebagai berikut, debit kalaulang 10 tahun $\left(\mathrm{Q}_{10 \text { thn }}\right)$ maksimal sebesar $0,108753 \mathrm{~m}^{3} /$ det, debit minimum sebesar $0,030072 \mathrm{~m}^{3} /$ det, debit air kotor yang terjadi pada sistem drainase di daerah Kelurahan Tihu akibat pertambahan jumlah penduduk sebesar $0,0000283 \mathrm{~m}^{3} / \mathrm{det}$ (debit maksimal) pada saluran $\mathrm{K} 1$ dan debit minimum terjadi pada saluran K15 sebesar $0,0000048 \mathrm{~m}^{3} / \mathrm{det}$.

3. Solusi penanggulangan debit limpasan yang terjadi pada sistem drainase di daerah Kelurahan Tihu terhadap beban debit yang harus di tampung terdapat beberapa saluran yang tidak mampu menampung beban debit sehingga perlu dievaluasi dengan memperbesar dimensi saluran dan normalisasi saluran yang ada seperti saluran nomor $\mathrm{K} 1$ dengan dimensi lebar $(B)$ 0,86 $\mathrm{m}$ dan tinggi $(H) 0,95 \mathrm{~m}$, saluran nomor $\mathrm{K} 2$ dengan dimensi lebar $(B) 0,86 \mathrm{~m}$ dan tinggi $(H) 0,95 \mathrm{~m}$, saluran nomor K7 dengan dimensi lebar $(B)$ $0,75 \mathrm{~m}$ dan tinggi $(H) 0,75 \mathrm{~m}$, saluran nomor $\mathrm{K} 12$ dengan dimensi lebar $(B)$ 0,50 $\mathrm{m}$ dan tinggi (H) 0,60 m, dan saluran nomor K14 dengan dimensi lebar $(B) 0,75 \mathrm{~m}$ dan tinggi $(H) 0,80 \mathrm{~m}$.

\subsection{Saran}

Dari hasil pembahasan dan kesimpulan yang dicapai dalam studi ini, maka untuk pengembangan hasil yang lebih baik disarankan sebagai berikut :

1. Kajian perubahan tata guna lahan, koefisien limpasa, debit limpasa, debit rencana dan debit air kotor dalam penelitian ini belum memperhitungkan perubahan iklim global yang terjadi dan perubahan intensitas hujan 20 tahun yang akan datang karena data curah hujan yang dipakai adalah data hujan 10 tahunan. Untuk pennelitian berikutnya untuk memperhitungkan perubahan iklim global dan data hujan yang di pakai 100 tahunan sehingga intensitas hujan tetap untuk debit rencana 20 tahun yang akan datang.

2. Perlu dilakukan upaya pembersihan berkala terhadap setiap saluran drainase agar kapasitas pengaliran tidak berkurang sehingga saluran mampu menampung debit rencana dan saluran drainase yang masih dapat menampung debit layanan perlu di lakukan pembersihan sedimennya.

3. Dalam penelitian ini penulis kesulitan mendapat data-data seperti; data curah hujan, peta topografi Kel. Tihu, peta masterplan Kel. Tihu, peta wilayah Kel. Tihu dan peta jaringan 
drainase. Untuk penelitian berikutnya sebelum melakukan penelitian di Kel. Tihu harus menyiapkan data-data tersebut.

\section{DAFTAR PUSTAKA}

[1] Betaubun. R. J, Suseno. D. H, Ussyandawayanty. 2012. Analisis Penanggulangan Genangan Di Kota Ambon pada Das Waitomu Kelurahan Uritetu, Jurnal Teknologi, Vol. 9 No.2.

[2] Faradina, A. Wijatmiko, I. Devia, Y. P. M. Anwar, R. 2018. Analisis Debit Limpasan Drainase Akibat Pengaruh Perubahan Tata Guna Lahan di Daerah Kota Surabaya Barat, Rekayasa Sipil, Vol. 12, No.2.

[3] Feriyanto, Erwin. 2016. Evaluasi Sistem Drainase Perkotaan Terhadap Tata Ruang Wilayah Kota Metro. Fakultas Teknik, Universitas Lampung. Lampung.

[4] Hasmar, Halim. 2012. Drainase Terapan. UII Press Yogyakarta. Yogyakarta.

[5] Saleh, Chairil. 2011. Kajian Penanggulangan Limpasan Permukaan Dengan Menggunakan Sumur Resapan (Studi Kasus di Daerah Perumnas Made Kabupaten Lamongan), Media Teknik Sipil, Vol.9, N0.2.

[6] Sinaga. M. R. dan Harahap. R. 2016. Analisis Sistem Saluran Drainase pada Jalan Perjuangan Medan, Educational Building, Vol.2. No.2.

[7] SNI 2415:2016. 2016. Tata Cara Perhitungan Debit Banjir Rencana. Badan Standardisasi Nasional. Bandung.

[8] Suripin, 2004. Sistem Drainase Perkotaan yang Berkelanjutan, Andi, Yogyakarta.

[9] Triatmodjo, B. 2008. Hidrologi Terapan, Beta Offset, Yogyakarta.

[10] Universitas Lampung. 2013. Pedoman Penulisan Karya Ilmiah Universitas Lampung. Unila Offset. Bandar Lampung.

[11] Van Rafi'i, Candra Hakim. 2013. Analisis Geospasial Perubahan Tata Guna Lahan Terhadap Daerah Aliran Sungai Kuripan Lampung. Fakultas Teknik, Universitas Lampung. Lampung. 